\title{
SEED MORPHOLOGY OF CALLUNA SALISB. (ERICACEAE)
}

\author{
Jaime FAGÚNDEZ \& Jesús IZCO
}

\begin{abstract}
Seed morphology of Calluna Salisb. (Ericaceae). Seed morphology of Calluna vulgaris (L.) Hull, the only species of Calluna Salisb. (Ericaceae), was studied. Seeds were collected and stored under cold and dry conditions. SEM pictures were taken for whole seeds and details. Measures were made for different quantitative characters. A complete description is given. Seeds are tiny (0.55$0.65 \mathrm{~mm}$ ), ellipsoid and with a reticulated pattern for testa sculpture, with the hilum region transformed into a pore. This character clearly distinguish Calluna seeds from those of Erica.
\end{abstract}

Keywords. Testa sculpture, Calluna vulgaris, SEM pictures

RESUMEN. Morfología de semillas de Calluna Salisb. (Ericaceae). Se estudia la morfología de las semillas de Calluna vulgaris (L.) Hull, única especie de Calluna Salisb. (Ericaceae). Las semillas se recolectaron y almacenaron en condiciones de baja humedad y temperatura. Se realizaron fotos de microscopía electrónica de semillas completas y de detalle. Se realizaron medidas de diferentes caracteres cuantitativos. Se realiza una descripción completa. Las semillas son pequeñas $(0.55-0.65$ $\mathrm{mm}$ ), elipsoidales y con una ornamentación de la testa reticulada. La región hilar se transforma en un poro, carácter que diferencia a Calluna del género próximo Erica.

Palabras clave: Ornamentación de la testa, Calluna vulgaris, fotografías de microscopía electrónica

\section{INTRODUCTION}

Calluna vulgaris (L.) Hull is a low shrub that occurs in different types of shrublands of holartic and western mediterranean Europe and NW Africa (fig. 1). It was originally described as part of Erica by Linnaeus (1753) (E. vulgaris L.) but many distinct characters led to its differentiation into a monospecific genus. Calluna has petaloid calyx exceeding the corolla and imbricate, decussated leaves.

Calluna is included in the subfamily Ericoideae, and was placed in a separated tribe, Calluneae, from the rest of the
Ericoideae by Stevens (1971), based on leaves and calyx characters, but also on its distinct pitted areas on the anticlinal walls of the testa cells of the seed. Later, Anderberg (1993) and Kron et al. (2002) considered that Calluna should be included in the tribe Ericeae because it forms a monophyletic group with Erica and the other genus of this tribe.

Seed morphology has not been commonly used in systematics in the Ericaceae, except for some works in Vaccinium (Vander Kloet, 1983), Monotropa (Olson, 1980), subfamily Pyroloideae (Takahashi, 1993) or Erica (Fraga, 1984). In 


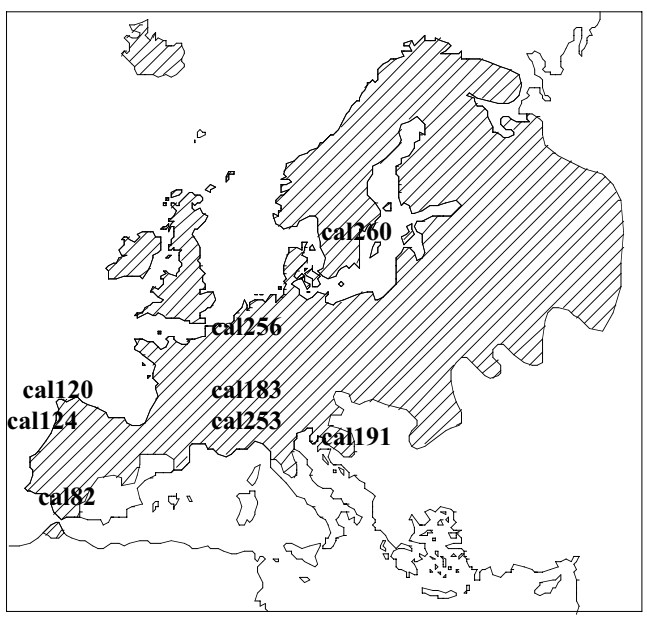

Figure 1. Distribution of Calluna vulgaris (L.) Hull. Location of populations studied. Distribución de Calluna vulgaris (L.) Hull. Localización de las poblaciones estudiadas.

other cases, some seed characters have been included in general systematic studies (Stevens, 1971; Anderberg, 1993; Judd \& Kron, 1993; Oliver, 2000; Kron, et al., 2002). Peltrisot (1904a, 1904b, 1904c) studied the anatomy and development of the seeds of Ericaceae, and Huckerby et al. (1972) and Wilson et al. (1973) studied seeds of Erica, Calluna and Bruckenthalia for fossil material identification.
Calluna was included in many of these works, and seeds have been used in many other studies mostly germination (Pons, 1989) or regeneration of heathlands (Granström, 1987; Barclay-Estrup \& Gimingham, 1994).

Recently, seed morphology has been used to solve some systematic problems in genus Erica (Fagúndez \& Izco, 2003a, $2003 \mathrm{~b}$ ). Seed characters have proved to be of a high systematic importance, and should be considered in any general study.

The aim of this study is to give a complete description of the seeds of Calluna including infraspecific variation, and consider the main differences with related genus, mostly Erica.

\section{MATERIALS AND METHODS}

Seeds were either collected in the field or sent from different seedbanks (tab. 1). 8 populations were studied, covering the whole geographical range of the species (fig. 1). Varieties or forms were not contemplated. Collected seeds were stored under cold and dry conditions following the procedures of the University of Santiago de Compostela Seedbank (Fagúndez, 2001).

\begin{tabular}{lll}
\hline Population & Locality & From \\
\hline cal82 & SPAIN: Huelva, Andévalo & J. Fagœendez \& D. Reyes, 8-99 \\
cal120 & SPAIN: Coruña, Carnota & J. Fagœndez \& R. Iglesias, 11-99 \\
cal124 & SPAIN: Coruña, Teo & J. Fagœndez \& A. Aguilar, 9-98 \\
cal183 & GERMANY & Botanischer Garten Univ. Göttingen \\
cal191 & SLOVENIA & Hortus botanicus univ. Ljubljana \\
cal253 & GERMANY: Tirol & L. Donaire, 8-00 \\
cal256 & BELGIUM: Namur & B. Pías, 9-01 \\
cal260 & SWEEDEN: Uppland, Nibble & G. Berggren 10-64 (A-L Anderberg, \\
& & Sweedish museum of N. History) \\
\hline
\end{tabular}

Table 1. Data of studied populations. Poblaciones estudiadas. 

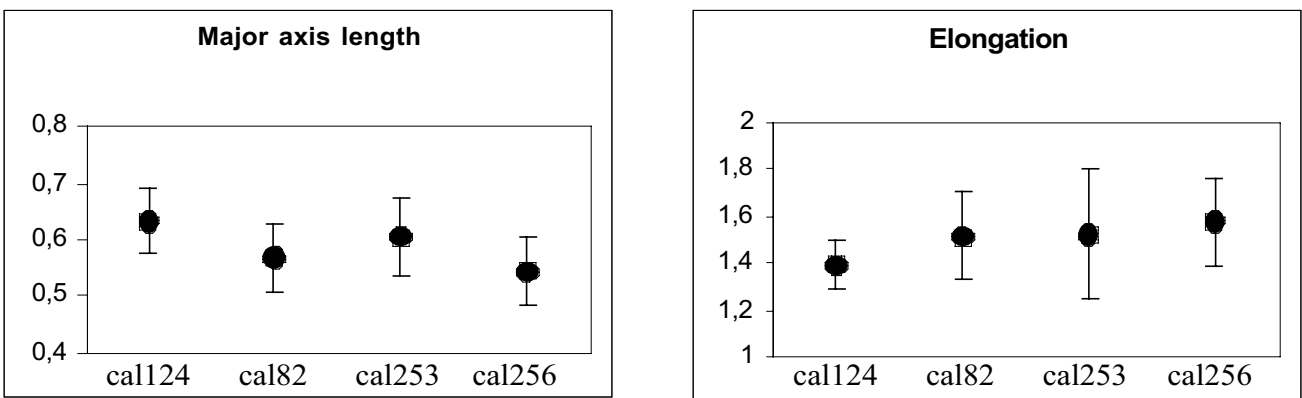

Figure 2. Representation of mean \pm standard deviation of major axis length $(\mathrm{mm})$ and elongation of seeds for the studied populations. Media \pm desviación típica de eje mayor $(\mathrm{mm})$ y elongación de las semillas de las poblaciones estudiadas.

Seeds of 4 populations were measured using a video-camera connected to a binocular scope. Images were treated by means of UTHSCSA Image tool software (San Antonio, Texas 1997). Area (a), perimeter (p), major axis length, minor axis length, elongation (Main axis/minor axis) and sinuosity $\left(4 \pi i a / p^{2}\right)$ were measured for each seed, mean and standard deviation were calculated for each population.

Seed weight was calculated for 100 seeds. A Munsell colour chart was used for colour determination.

For SEM pictures, 5-10 dry seeds from 2 populations were mounted on metal stubs using double-stick tape and gold-coated. Pictures of whole seed and detail were taken from three seeds of each population.

Nomenclature used for description purposes is that of Berggren (1981) and Barthlott (1981, 1984).

\section{RESULTS}

\section{Seed description}

Calluna vulgaris (L.) Hull. Seeds yellowish red. Weight around $0.025 \mathrm{mg}$. Seeds mostly ellipsoid or broadly ellipsoid in outline, sometimes oblong, oval or circular. Circular or slightly elliptic in shape. 0.55-0.65 mm long, 0.35-0.45 mm wide. Axis ratio 3:2. Without appendages. Terminal hilum, constituted by a pore of diameter 0.1 $0.3 \mathrm{~mm}$ with a deep cavity surrounded by the seed coat and a fleshy irregular tissue at the bottom. Seed surface alveolatedreticulated, with 6-7 cells in main axis.

\begin{tabular}{lccccccc}
\hline population & $\boldsymbol{N}$ & Area & Perimeter & Major axis & Minor axis & Elongation & Sinuosity \\
\hline cal124 & 12 & $0,22 \pm 0,05$ & $2,48 \pm 0,28$ & $0,63 \pm 0,06$ & $0,46 \pm 0,05$ & $1,39 \pm 0,10$ & $0,44 \pm 0,03$ \\
cal82 & 26 & $0,16 \pm 0,03$ & $1,79 \pm 0,21$ & $0,56 \pm 0,06$ & $0,38 \pm 0,04$ & $1,50 \pm 0,19$ & $0,65 \pm 0,07$ \\
cal253 & 15 & $0,19 \pm 0,04$ & $2,01 \pm 0,18$ & $0,60 \pm 0,07$ & $0,41 \pm 0,06$ & $1,51 \pm 0,27$ & $0,57 \pm 0,04$ \\
cal256 & 29 & $0,15 \pm 0,03$ & $1,79 \pm 0,17$ & $0,54 \pm 0,06$ & $0,35 \pm 0,04$ & $1,57 \pm 0,19$ & $0,57 \pm 0,04$ \\
\hline
\end{tabular}

Table 2. Mean \pm standard deviation of seed characters. All values in mm except for area $\left(\mathrm{mm}^{2}\right)$, elongation and sinuosity. Media \pm desviación típica de los caracteres seminales. Todos los valores en $\mathrm{mm}$ excepto area $\left(\mathrm{mm}^{2}\right)$, elogación y sinuosidad. 

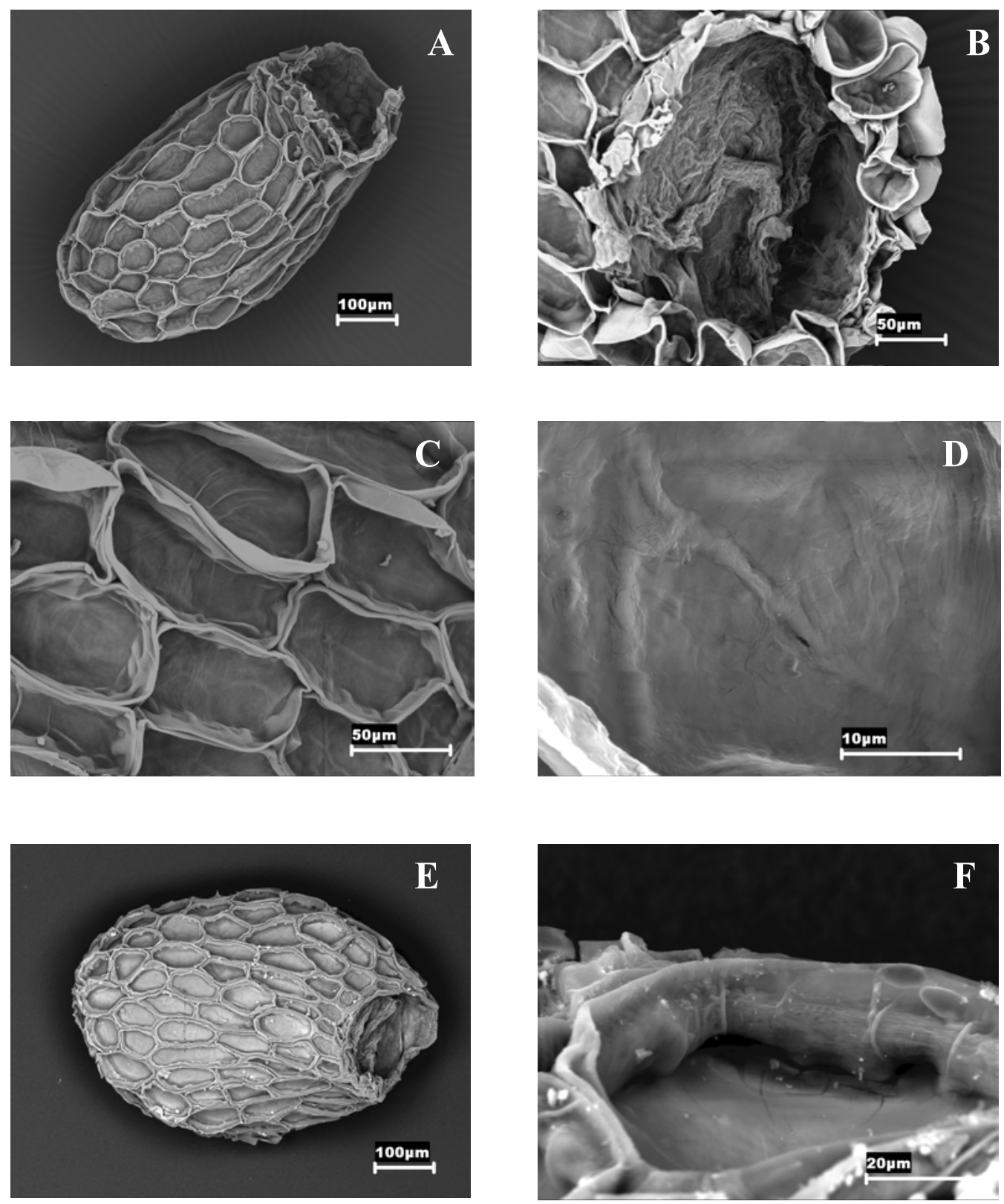

Figure 3. A: cal120. Whole seed; B: cal120. Pore of the hilum region, with a fleshy structure surrounded by the testa; C: cal120. Surface cells of the seed; D: cal120. Outer periclinal wall; E: cal124. Whole seed; F: cal124. Outer anticlinal wall. 
Surface cells irregularly polygonal, mostly hexagonal, with straight borders, in contact with (5) - 6 - (7) surrounding cells. Cells of $0.1-0.05 \times 0.05$, isodiametric or elongated with axis ratio up to $2: 1$. Outer anticlinal walls thin, $0.02 \mathrm{~mm}$ high, sometimes bending over the inside of the cell. Outer periclinal smooth or with an irregularly branched secondary ornamentation. Cell boundaries always channelled.

\section{Variation at population level}

Seed characters, in terms of size (major axis length) and shape (elongation), are similar for the studied populations (tab. 2, fig. 2). Numerical values overlap for most variables (fig. 2). No differences were also observed for shape of testa cells, testa sculpture, hilum structure or boundaries of testa cells. No relation is stablished between populations in terms of geographical distribution.

\section{DISCUSSION}

The presence of a pore interrupting the seed coat is exclusive of

Calluna within the Ericoideae. This comes from the micropilar cavity, where the endosperm forms the micropilar haustoria observed in many other Ericaceae (Peltrisot, 1904a; Stevens, 1971; Olson, 1980; Anderberg, 1993; Judd \& Kron, 1993), but only in Calluna stands out of the seed and separates from the seed in later stages of maturity, leaving this pore (Peltrisot, 1904b). Erica seeds present a terminal or subterminal hilum that is a scar from the funiculum.

As for testa sculpture, ornamentation of Calluna is similar to some species of Erica like E. erigena R. Ross (Fagúndez \& Izco, 2003a) that has thin outer anticlinal walls, and irisated shades that might be due to the presence of epicuticular waxes (Barthlott,
1981).

Peltrisot (1904b) and Stevens (1971) mention pitted areas in anticlinal and outer periclinal walls, that we have not observed (see SEM pictures D, F).

Our data mostly agree with those of Fraga (1983), Huckerby et al. (1972) and Villar (1993), with similar values for size and shape of seeds and ornamentation description.

Brisson \& Peterson (1977) and Wyatt (1984) claim for a cautious approach in the employ of SEM in the study of seed morphology. They point out that a good infraspecific representation is needed for taking conclusions, mostly if a taxonomic innovation is presented. In this case, no significant differences are found among studied populations and the description presented contemplates the whole infraspecific variation.

In our opinion seed characters have systematic importance and should be considered in general studies in this family. Calluna seeds have differences from other Ericoideae in seed morphology result of a distinct seed development, the most important is the presence of a pore in the hilum region which clearly distinguish Calluna from Erica.

ACKNOLEDGEMENTS. We would like to thank every person or institution that has provided seeds for this study (see tab. 1).

\section{REFERENCES}

ANDERBERG, A. A. -1993- Cladistic interrelationships and major clades of the Ericales. Plant Syst. and Evol. 184: 207-231.

BARCLAY-ESTRUP, P. \& C. H. GIMINGHAM -1994- Seed-sheding in a Scottish heath community. J. of Veget. Sci. 5: 197-204.

BARTHLOTT, W. -1981- Epidermal and seed surface characters of plants: systematic 
applicability and some evolutionary aspects. Nordic J. of Bot. 1: 345-355.

BARTHLOTT, W. -1984- Microstructural features of seed surface. In : HEYWOOD, V. H. \& MOORE, D. M. (eds.): Current concepts in Plant Taxonomy. Academic Press, London.

BERGGREN, G. -1981- Atlas of seeds Vol. III. Swedish Natural Science Research Council, Stockholm.

BRISSON, J. D. \& R. L. PETERSON -1977- The scaning electron microscope and X-ray microanalysis in the study of seeds: a bibliography covering the period 1967-1976. Scanning Electron Microscopy (IIT Research Inst. Chicago) 2: 697-712.

FAGÚNDEZ, J. -2001- Técnicas de conservación e identificación de semillas en el género Erica L. en Europa. Tesis de licenciatura. Universidade de Santiago de Compostela.

FAGÚNDEZ, J. \& J. IZCO -2003a- Seed morphology of Erica L. Sect. Callicodon Bentham. Plant biosystems 137: 111-116.

FAGÚNDEZ, J. \& J. IZCO -2003b- Seed morphology of Erica L. Sect. Chlorocodon Bentham. Acta Bot. Gallica 150(4): 401-410.

FRAGA, M. I. -1983- Notes on the morphology and distribution of Erica and Calluna in Galicia, North-Western Spain. Glasra 7: 1123.

FRAGA, M. I. -1984- Valor taxonómico de la morfología de las semillas en las especies del genero Erica presentes en el NO de España. Acta Bot. Malacitana 9: 147-152.

GRANSTRÖM, A. -1987- Seed viability of fourteen species during five years of storage in a forest soil. $J$. of Ecol. 75: 321-331.

HUCKERBY, E., R. MARCHANT \& F. OLDFIELD -1972- Identification of fossil seeds of Erica and Calluna by Scanning Electro Microscopy. New Phytol. 71: 387-392.

JUDD, W. S. \& K. A. KRON -1993-Circumscription of Ericaceae (Ericales) as determined by preliminary cladistic analyses based on morphological, anatomical, and embryological features. 'Brittonia 45(2): 99-114.

KRON, K. A., W. S. JUDD, P. F. STEVENS, D. M. CRAYN, A. A. ANDERBERG, P. A. GADEK, C. J. QUINN \& J. L. LUTEYN 2002- Phylogenetic classification of Ericaceae: Molecular and morphological evidence. The Bot. Review 68(3): 335-423.
LINNAEUS, C. -1753-Species Plantarum. Stockholm.

OLIVER, E. G. H. -2000- Systematics of Ericeae (Ericaceae: Ericoideae) species with indehiscent and partially dehiscent fruits. Contributions from the Bolus Herbarium 19: 1-483.

OLSON, A. R. -1980- Seed morphology of Monotropa uniflora L. (Ericaceae). Amer. J. of Bot. 67(6): 968-974.

PONS, T. L. -1989- Dormancy and germination of Calluna vulgaris (L.) Hull and Erica tetralix L. seeds. Acta Oecologica Oecol. Plant. 10(1): 35-43.

PELTRISOT, M. C. N. -1904a- Développement et structure de la graine de quelques Éricacées. Note préliminaire. J. de botanique. 18: 234-242.

PELTRISOT, M. C.-N. -1904b- Développement et structure de la graine de quelques Éricacées. J. de botanique. 18: 309-367.

PELTRISOT, M. C.-N. -1904c- Développement et structure de la graine de quelques Éricacées. J. de botanique. 18: 386-402.

STEVENS, P. F. -1971-A classification of the Ericaceae: Subfamilies and tribes. - J. Linn. Soc., Bot. 64: 1-53.

TAKAHASHI, H. -1993- Seed morphology and its systematic implications in Pyroloideae (Ericaceae). - Int. J. of Plant Sci. 154(1): 175186.

VANDER KLOET, S. P. -1983- Seed and seedling characters in Vaccinium gr. myrtillus. - Le Nat. Canadien. 110: 285-292.

VILLAR, L. -1993- Calluna Salisb. In: CASTROVIEJO, S. et al. (eds.) Flora Iberica Vol. IV. R.J.B., C.S.I.C. Madrid.

WILSON, D. G., R. MARCHANT \& F. OLDFIELD -1973- Fossil seeds of Erica from the Cromer forest bed series. New Phytol. 72: 1235-1237.

WYATT, R. -1984- Instraspecific variation in seed morphology of Arenaria uniflora (Caryophyllaceae). Syst. Bot. 9(4): 423-431.

Aceptado para su publicación en septiembre de 2004

Dirección de los autores. Departamento de Botánica. Facultad de Farmacia, Universidad de Santiago de Compostela, 15706 - Santiago de Compostela, A Coruña, España 